\title{
Temporally changing drivers for late-Holocene vegetation changes on the northern Tibetan Plateau
}

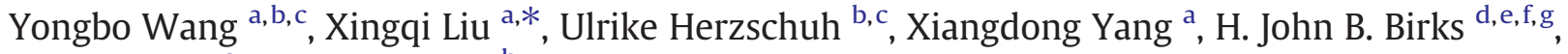 \\ Enlou Zhang a , Guobang Tong ${ }^{\mathrm{h}}$
}

a State Key Laboratory of Lake Science and Environment, Nanjing Institute of Geography and Limnology, Chinese Academy of Sciences, 210008 Nanjing, PR China

${ }^{\mathrm{b}}$ Alfred Wegener Institute for Polar and Marine Research, Research Unit Potsdam, 14473 Potsdam, Germany

${ }^{\mathrm{c}}$ Institute of Earth and Environment Science, University of Potsdam, 14476 Potsdam, Germany

' Department of Biology, University of Bergen, Thormøhlensgate 53A, N-5006 Bergen, Norway

e Bjerknes Centre for Climate Research, Allegaten 55, N-5007 Bergen, Norway

${ }^{\mathrm{f}}$ Environmental Change Research Centre, University College London, London, WC1E 6BT, UK

' School of Geography and the Environment, University of Oxford, Oxford, OX1 3QY, UK

${ }^{\mathrm{h}}$ Institute of Hydrological and Environmental Geology, Chinese Academy of Geological Sciences, 050803 Zhengding, PR China

\section{A R T I C L E I N F O}

\section{Article history:}

Received 29 November 2011

Received in revised form 30 May 2012

Accepted 28 June 2012

Available online 8 July 2012

\section{Keywords:}

Asian Summer Monsoon

Late-Holocene

Pollen

Procrustes analysis

Redundancy analysis

Tibetan Plateau

Vegetation

Westerlies

\begin{abstract}
A B S T R A C T
Fossil pollen records have been widely used as indicators of past changes in vegetation and variations in climate. The driving mechanisms behind these vegetation changes have, however, remained unclear. In order to evaluate vegetation changes that have occurred in the northern part of the Tibetan Plateau and the possible drivers behind these changes, we have applied a moving-window Redundancy Analysis (RDA) to high resolution (10-15 years) pollen and sedimentary data from Lake Kusai covering the last 3770 years. Our analyses reveal frequent fluctuations in the relative abundances of alpine steppe and alpine desert components. The sedimentary proxies (including total organic carbon content, total inorganic carbon content, and "end-member" indices from grain-size analyses) that explain statistically some of the changes in the pollen assemblage vary significantly with time, most probably reflecting multiple underlying driving processes. Climate appears to have had an important influence on vegetation changes when conditions were relatively wet and stable. However, a gradual decrease in vegetation cover was identified after 1500 cal a BP, after which the vegetation appears to have been affected more by extreme events such as dust-storms or fluvial erosion than by general climatic trends. Furthermore, pollen spectra over the last 600 years are shown by Procrustes analysis to be statistically different from those recovered from older samples, which we attribute to increased human impact that resulted in unprecedented changes to the vegetation composition. Overall, changes in vegetation and climate on the northern part of the Tibetan Plateau appear to have roughly followed the evolution of the Asian Summer Monsoon. After taking into account the highly significant millennial (1512 years) periodicity revealed by time-series analysis, the regional vegetation and climate changes also show variations that appear to match variations in the mid-latitude westerlies.
\end{abstract}

(c) 2012 Elsevier B.V. All rights reserved.

\section{Introduction}

Significant vegetation changes during the Holocene, deduced from fossil pollen data, have been reported from the Tibetan Plateau (e.g. Gasse et al., 1991; Shen et al., 2008; Tang et al., 2009; Herzschuh et al., 2010a, 2011) and have subsequently been interpreted in terms of climatic variations through the application of pollen-climate calibration functions (Shen et al., 2006; Herzschuh et al., 2010b; Lu et

\footnotetext{
* Corresponding author at: State Key Laboratory of Lake Science and Environment, Nanjing Institute of Geography and Limnology, Chinese Academy of Sciences, East Beijing Road 73, 210008 Nanjing, PR China. Tel.: + 86258688 2108; fax: + 862557713063.

E-mail address: xqliu@niglas.ac.cn (X. Liu).
}

al., 2011). However, the relationship between vegetation and climate is not straightforward because of the non-linear response of vegetation to various climate parameters and related feedback mechanisms.

Precipitation is commonly assumed to be highly correlated with Tibetan vegetation composition due to the limited moisture supply available in this region, and variations in pollen spectra have mainly been interpreted in terms of variations in precipitation (Shen et al., 2006; Herzschuh et al., 2010b; Lu et al., 2011). However, by analysing pollen records in peat deposits, Zhao et al. (2011) revealed more complex responses to climatic conditions, such as insolation-driven temperature changes that act in concert with variations in monsoon-derived precipitation. Recent results from a transient global climate model covering the last 6000 years demonstrate that the influence that temperature changes have had on Tibetan Plateau 
vegetation may have been underestimated (Dallmeyer et al., 2011). Changes in atmospheric $\mathrm{CO}_{2}$ concentrations have also recently been suggested to be the major driver for mid-Holocene vegetation turnover on the Tibetan Plateau (Herzschuh et al., 2011). In contrast, Miehe et al. (2011) suggested that Tibetan ecosystems remained ecologically stable during the mid-Holocene, due to the dominance of climatically resilient species. In addition to these studies that have attributed ecological transitions to climatic variability, vegetation change has also been assumed to reflect the intensity of nomadic herding on the Tibetan Plateau (Miehe et al., 2009; Schlütz and Lehmkuhl, 2009).

An improved understanding of the driving mechanisms behind vegetation changes and associated interactions during the Holocene is urgently required if future impacts of climate and human activity on the unique Tibetan ecosystems are to be predicted. It would also allow the use of pollen sequences as a climate proxy to be more reliably exploited. Such information is of particular interest for the central-northern parts of the Tibetan Plateau, where the vegetation may be more sensitive to climatic change owing to the interactions between the Asian Summer Monsoon (ASM) and the westerly winds (Wang et al., 2005; Vandenberghe et al., 2006; Liu et al., 2009). However, because of its remoteness, palaeoenvironmental studies from that part of Tibetan Plateau are scarce and no information is available about the drivers behind the vegetation changes (Wang et al., 2010).

In this study we present a high resolution late-Holocene pollen sequence from Lake Kusai, on the northern part of the Tibetan Plateau. Our main objectives are (1) to reconstruct the late-Holocene vegetation and climate changes for the northern part of the Tibetan Plateau, (2) to identify the underlying driving mechanisms for vegetation changes by evaluating the correlations between vegetation changes and environmental changes on the basis of pollen and sedimentary proxies from the same core (Liu et al., 2009), for which a movingwindow constrained ordination analysis (Redundancy Analysis RDA) was applied, and (3) to assess the possible influences that human impacts have had on the northern part of the Tibetan Plateau, which are little known at present.

\section{Study area}

Lake Kusai (approximately $35.62-35.83^{\circ} \mathrm{N}$ and $92.63-93.25^{\circ} \mathrm{E}$ ) is a closed basin situated about $4475 \mathrm{~m}$ a.s.l. on the northern part of the
Tibetan Plateau (Fig. 1). It covers an area of about $255 \mathrm{~km}^{2}$ and has a catchment area of approximately $3700 \mathrm{~km}^{2}$. The lake is fed mainly from the south-west by the Kusai River, which originates to the west of the lake on the Daxue Mountain. The lake is rather shallow in the south-east where the mean water depth is about $10 \mathrm{~m}$, but is much deeper in the north-west, with depths of up to about $50 \mathrm{~m}$ in the centre of the sub-basin (Li, 1996; Wang and Dou, 1998). The 30year records available from the nearest meteorological station at Wudaoliang $\left(35.22^{\circ} \mathrm{N}, 93.08^{\circ} \mathrm{E}\right)$, about $50 \mathrm{~km}$ from Lake Kusai, indicate a mean annual temperature of about $-5.4{ }^{\circ} \mathrm{C}$, a mean annual precipitation of $275 \mathrm{~mm}$, and a potential annual evaporation of about $1300 \mathrm{~mm}$ (China Meteorological Administration, unpublished data).

As a result of the limited precipitation and high elevation, alpine steppe plant communities dominate the present-day vegetation surrounding Lake Kusai (Hou, 2001). The immediate vicinity of the lake is covered by Carex moorcroftii alpine steppe to the west and Stipa purpurea alpine steppe to the east. The western sections of the high elevation Kulun Mountains are dominated by Saussurea medusa and Saussurea spp. sparse vegetation, while Arenaria musciformis and Androsace tapete cushion vegetation is distributed on the eastern sections. Alpine steppe (C. moorcroftii, S. purpurea) vegetation is present on the northern slopes of the Kunlun Mountains. Patches of alpine meadow (mainly Kobresia pygmaea) can also be found in the mountainous areas, where there is a greater availability of moisture, with patches of alpine shrubs (Salix orithrepha). Saussurea spp., and Potentilla spp. occur in sheltered areas (Hou, 2001).

\section{Materials and methods}

\subsection{Coring, chronology, and sedimentary proxy analyses}

Two long sediment cores $(637 \mathrm{~cm}$ and $592 \mathrm{~cm}$ long, measured in field) were collected in 2006 from a water depth of $14.5 \mathrm{~m}$ in the south-eastern part of Lake Kusai, using UWITEC coring equipment (Fig. 1). A short core of $17 \mathrm{~cm}$ length was also recovered in the vicinity of the long cores using a gravity corer. Overlaps between the long cores were identified using scanned magnetic susceptibility data, resulting in a $606 \mathrm{~cm}$ continuous sediment record. Sub-samples at $1 \mathrm{~cm}$ intervals were taken in the laboratory for further analyses.

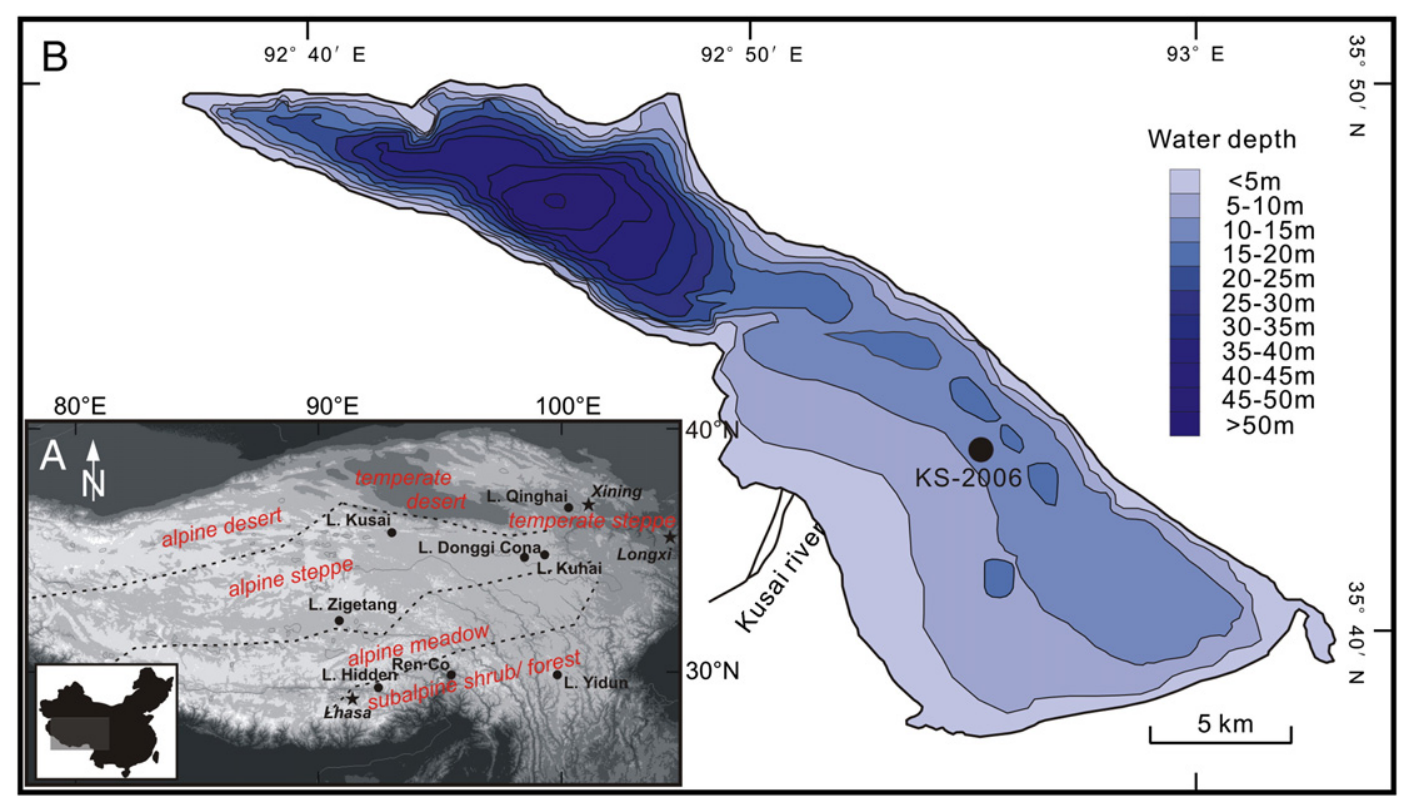

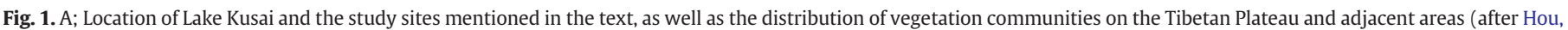
2001); B: bathymetry of Lake Kusai and the location of KS-2006 core. 
Because of the absence of terrestrial plant macrofossils and the low pollen concentrations, ${ }^{14} \mathrm{C}$ dating of total organic carbon samples was carried out using accelerator mass spectrometry (AMS). Samples from seven different levels were processed and dated at the Radiocarbon Laboratory, University of Tokyo, Japan (Table 1 ). In addition, ${ }^{210} \mathrm{~Pb}$ and ${ }^{137} \mathrm{Cs}$ radiometric-dating results from the short core were used to determine the "Carbon Reservoir Effect", which has been commonly reported from lake sediments on the Tibetan Plateau (Fontes et al., 1996; Shen et al., 2005; Morrill et al., 2006; Henderson et al., 2010), yielding a Carbon Reservoir Effect of about 3400 years. All ${ }^{14} \mathrm{C}$ ages were then corrected for this effect, calibrated using the Calib 5.1 program and the INTCAL04 calibration data-set (Reimer et al., 2004), and interpolated and extrapolated to obtain estimated ages for each horizon. The age obtained for the bottom of the core was $3770 \mathrm{cal}$ a BP.

Measurements of the sedimentary proxies, i.e. total organic carbon (TOC) content, total inorganic carbon (TIC) content, and grain sizes, were performed at $2 \mathrm{~cm}$ intervals, representing a 10 to 15 year resolution. The End-Member Modelling Algorithm (EMMA) of Weltje (1997), which converts measured grain-size distributions into proportional contributions of an optimal set of end-members (Weltje and Prins, 2003, 2007), was used to determine the end-members (EMs) from the total set of grain-size measurements. Detailed descriptions and discussions concerning the measurements and core chronology are in Liu et al. (2009).

\subsection{Pollen analyses}

Pollen samples collected at $2 \mathrm{~cm}$ intervals (303 samples in total) were treated and analysed following standard laboratory procedures that included treatment with hydrogen chloride $(\mathrm{HCl}, 10 \%)$, potassium hydroxide ( $\mathrm{KOH}, 10 \%)$, and hydrofluoric acid ( $\mathrm{HF}, 50 \%)$, as well as acetolysis, fine sieving (with $7 \mu \mathrm{m}$ mesh in an ultrasonic bath), and mounting in glycerin (Fægri and Iversen, 1989). Two tablets of Lycopodium spores were added to the fossil samples in order to estimate absolute pollen concentrations. A minimum of 300 terrestrial pollen grains were counted from each sample and the pollen content calculated as a percentage of the total pollen from both arboreal and terrestrial non-arboreal pollen taxa.

\subsection{Numerical analyses}

Only those pollen taxa that occurred with a frequency greater than $0.5 \%$ in at least five samples were included in the numerical analyses and in the compilation of the pollen diagrams. These diagrams were generated using TGView (version 2.0.2) (Grimm, 1991), and the pollen-assemblage zone boundaries were defined on the basis of

Table 1

AMS dating results and corresponding calibrated ages used to construct the age-depth model for the KS-2006 core.

\begin{tabular}{|c|c|c|c|c|c|c|}
\hline $\begin{array}{l}\text { Sample } \\
\text { No. }\end{array}$ & $\begin{array}{l}\text { Laboratory } \\
\text { Code }\end{array}$ & $\begin{array}{l}\text { Depth } \\
(\mathrm{cm})\end{array}$ & $\begin{array}{l}\text { Dated } \\
\text { material }\end{array}$ & $\begin{array}{l}{ }^{14} \mathrm{C} \text { ages } \\
(\mathrm{a} B \mathrm{BP})\end{array}$ & $\begin{array}{l}\text { Ages } \\
\text { corrected } \\
\text { by } 3400 \text { yr } \\
\text { (a BP) }\end{array}$ & $\begin{array}{l}\text { Calendar } \\
\text { ages } \\
\text { (cal a BP) } \\
\text { by } 2 \sigma\end{array}$ \\
\hline Ks1-1-82 & ТКа-14104 & $82-83$ & TOC & $3670 \pm 35$ & $270 \pm 30$ & $\begin{array}{l}281-335 \\
(308)\end{array}$ \\
\hline Ks1-1-102 & TKa-14105 & $102-103$ & TOC & $3855 \pm 30$ & $455 \pm 35$ & $\begin{array}{l}478-536 \\
(530)\end{array}$ \\
\hline Ks1-2-26 & TKa-14107 & 184-185 & TOC & $4580 \pm 35$ & $1180 \pm 45$ & $\begin{array}{l}1047-1180 \\
(1100)\end{array}$ \\
\hline Ks1-2-126 & TКа-14109 & 284-285 & TOC & $5235 \pm 35$ & $1835 \pm 35$ & $\begin{array}{l}1698-1868 \\
(1850)\end{array}$ \\
\hline Ks1-3d-66 & TKa-14234 & $470-471$ & TOC & $6257 \pm 45$ & $2875 \pm 50$ & $\begin{array}{l}2871-3084 \\
(2900)\end{array}$ \\
\hline Ks1-4-70 & TKa-14112 & $573-574$ & TOC & $6630 \pm 40$ & $3230 \pm 65$ & $\begin{array}{l}3377-3557 \\
(3550)\end{array}$ \\
\hline Ks1-4-100 & TKa-14113 & 603-604 & TOC & $6955 \pm 40$ & $3555 \pm 50$ & $\begin{array}{l}3718-3930 \\
(3750)\end{array}$ \\
\hline
\end{tabular}

results from a Constrained Incremental Sum of Squares (CONISS) cluster analysis, using the Edwards and Cavalli-Sforza's chord distance in TGView (version 2.0.2).

To evaluate the potential noise in our high resolution pollen data, a spectral analysis was applied to the Artemisia content (in percentages) using the REDFIT (version 3.8) program, which was designed to estimate red-noise spectra directly from unevenly spaced palaeoclimatic time series (Schulz and Mudelsse, 2002). Strong multi-decadal scale noise (ca. 30 years) was identified (Fig. 2A), which, in view of our sampling resolution of about 15 years, was thought to represent inter-sample variations. Since we were mainly focusing on long-term trends, all the data (both pollen and sedimentary proxies) were then interpolated and re-sampled at 15 year intervals in order to reduce such multi-decadal scale noise (Fig. 2B). This was achieved using AnalySeries 2.0.4.2 software (Paillard et al., 1996). All numerical analyses were thereafter performed using these re-sampled interpolated data.

Pollen percentages were square-root transformed for numerical analyses to stabilise variances and optimise the signal-to-noise ratio. Detrended correspondence analysis (DCA; Hill and Gauch, 1980) yielded turnover gradients of 0.99 standard deviations, indicating that linear-based methods such as Principal Component Analysis (PCA) and Redundancy Analysis (RDA) are appropriate for this data-set.

We used the pollen assemblages and parallel sedimentary proxies (TOC, TIC, and end-members from grain-size analyses) from the same core in order to avoid any potential chronological uncertainties. In order to test for potential collinearities, Pearson correlation coefficients were calculated among our sedimentary proxies as well as in a PCA analysis. Generally, strong collinearities among TOC, TIC, and end-member four (EM4) were detected. Because of this the latter two proxies were excluded from further numerical analyses. Using pollen data as response variables, the sedimentary proxies as environmental or predictor variables with depth as a covariable, a
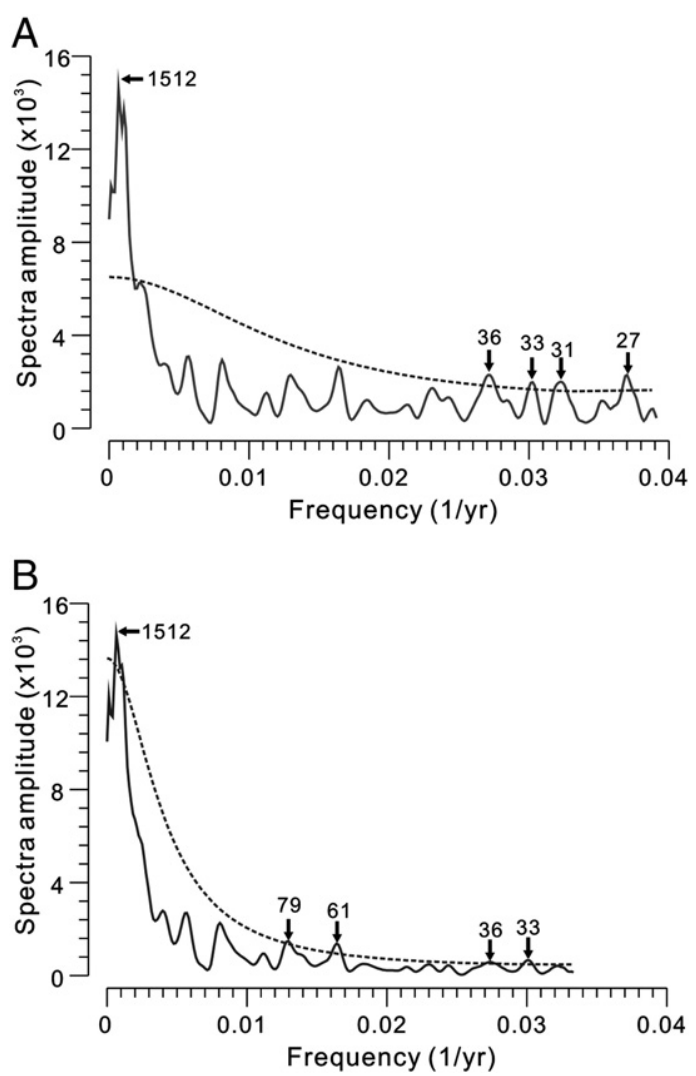

Fig. 2. Results of spectral analyses using the original Artemisia percentages (A) and resampled data (B). The dashed lines indicate $90 \%$ confidence levels. 


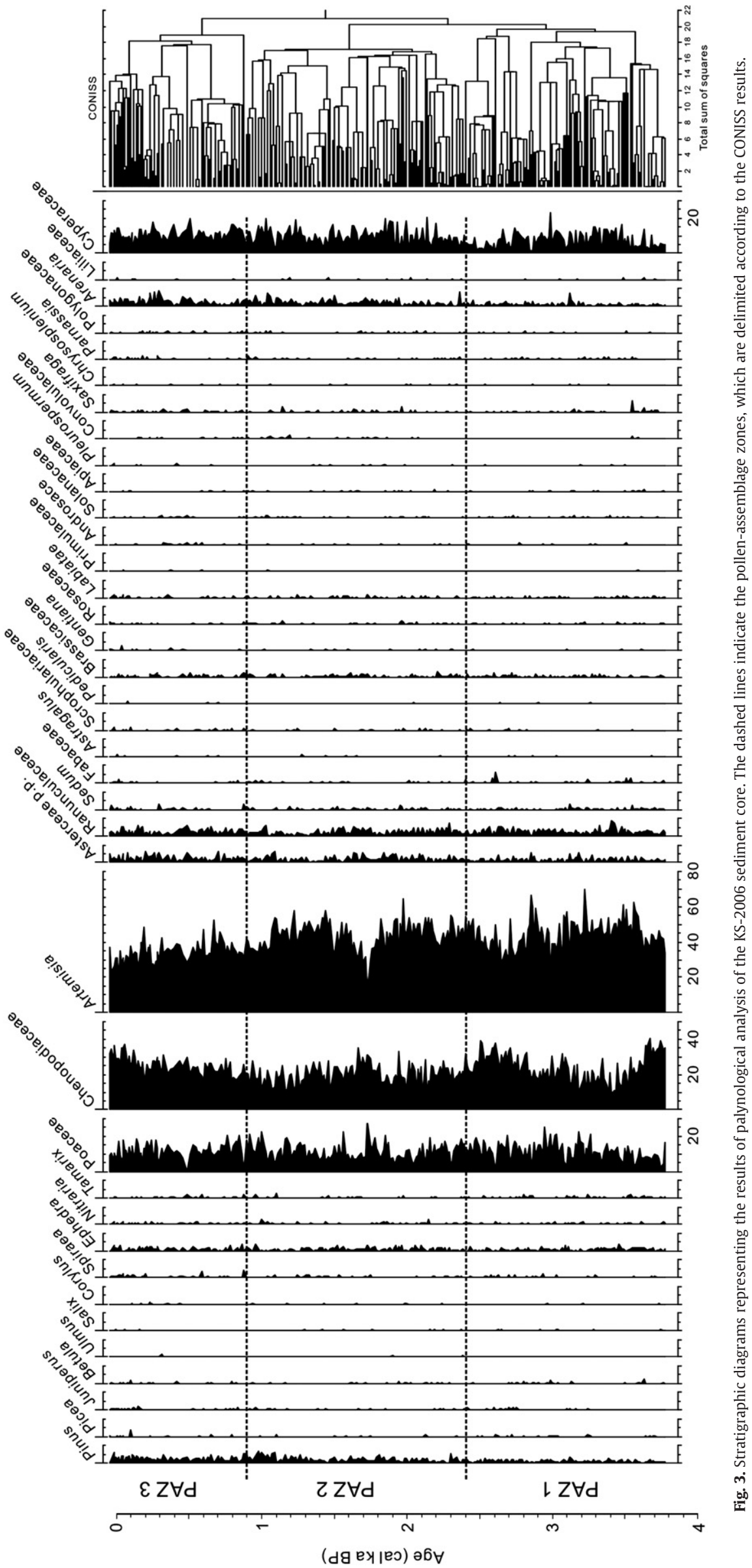



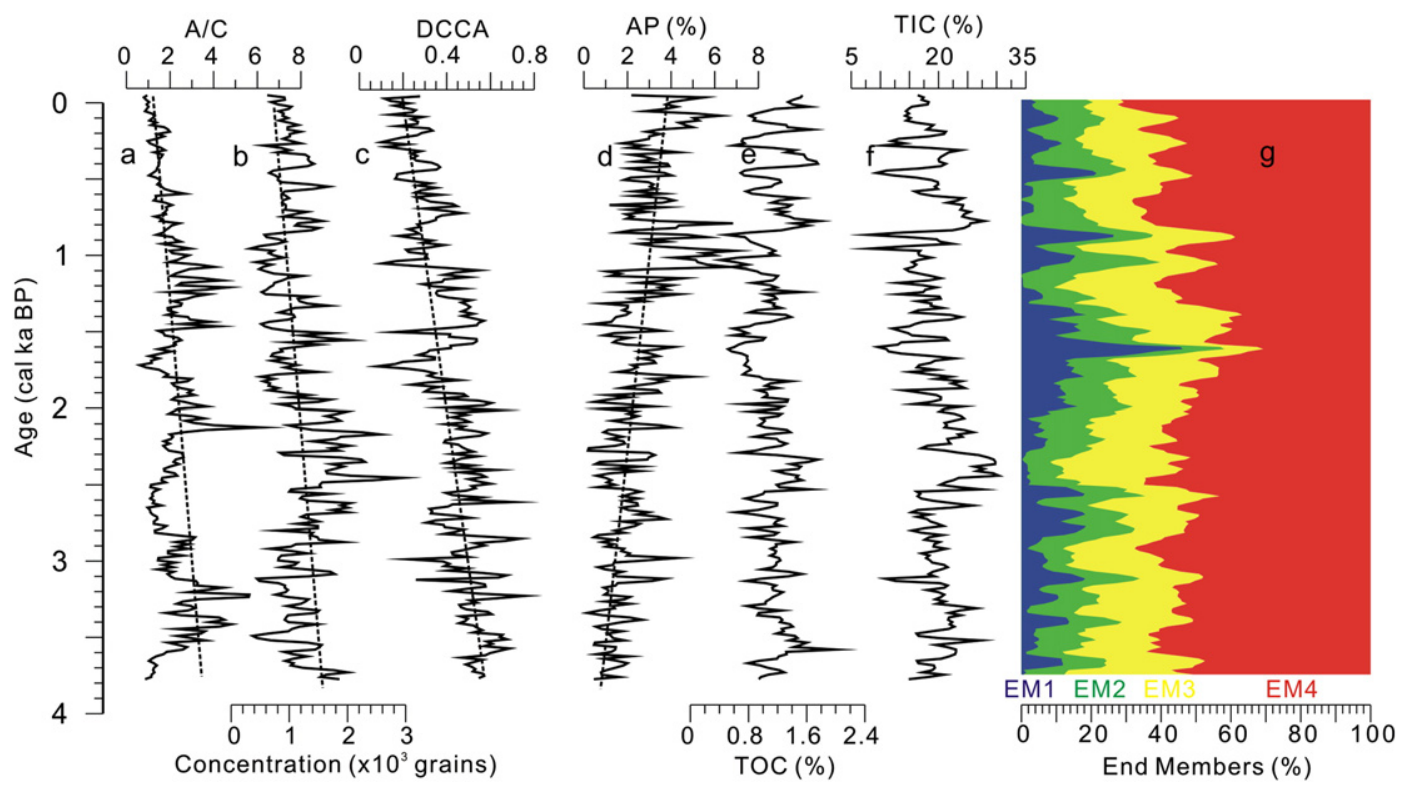

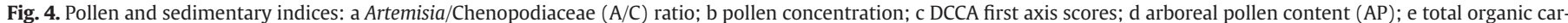
bon (TOC) content; f total inorganic carbon (TIC) content; g, proportions of four end members (EM1-4). The dashed lines indicate the general trends for individual indices.

moving-window RDA was carried out to assess temporal variations in correlations in terms of the contribution and statistical significance for each proxy. The moving-window approach was first used by Bradshaw et al. (2005) and subsequently by Mortensen et al. (2011). In general, every 40 stratigraphically-continuous samples were grouped and analysed together. A forward selection option in RDA was used, together with a Monte Carlo permutation test (999 restricted permutations), to determine the relative contribution and significance of the sedimentary proxies for each group. Bonferroni corrections were applied to adjust the significance levels of the $p$-values because of multiple comparisons (Weisstein, 2012).

To estimate the amount of compositional turnover along the time gradients, a Detrended Canonical Correspondence Analysis (DCCA) constrained by sample ages was applied using the transformed pollen percentage data of our 255 samples. All ordination analyses (DCA, PCA, RDA and DCCA) were carried out using CANOCO version 4.5 (ter Braak and Šmilauer, 2002).

To examine further the temporal variations in the pollen correlations along the core, the pollen sequence was classified into six continuous sections (KSH 1-6, following the chronological order) with 40 samples in each ( 55 samples in the oldest section, KSH 1). The rare species with a maximum abundance under $3 \%$ were removed to reduce statistical noise. Correlation matrices between pollen species for each section were calculated after applying Aitchison's (1990) log-centring transformation to minimise the closed percentage effect. The correlation matrices were then subjected to Principal Coordinates Analysis (PCoA), and the subsequent configurations were used for Procrustes and ProTest Analyses (Wischnewski et al., 2011). The analyses were accomplished in $\mathrm{R}$ using packages including vegan, stats, compositions

Table 2

Correlation coefficients between the sedimentary proxies.

\begin{tabular}{|c|c|c|c|c|c|c|}
\hline & TOC & TIC & EM1 & EM2 & EM3 & EM4 \\
\hline TOC & & 0.60 & -0.50 & 0.00 & -0.03 & 0.54 \\
\hline TIC & & & -0.53 & 0.07 & 0.19 & 0.38 \\
\hline EM1 & & & & -0.14 & -0.36 & -0.70 \\
\hline EM2 & & & & & -0.28 & -0.21 \\
\hline EM3 & & & & & & -0.20 \\
\hline EM4 & & & & & & \\
\hline
\end{tabular}

and ape (Paradis et al., 2004; Oksanen et al., 2011; R Development Core Team, 2011; van den Boogaart et al., 2011).

\section{Results}

\subsection{Late-Holocene pollen record from Lake Kusai}

A total of 77 terrestrial pollen types were identified and 38 taxa are included in the pollen diagram and numerical analyses. The pollen assemblages consist mainly of four taxa of herbaceous or shrub pollen that commonly appear in arid and semi-arid parts of China, i.e. Artemisia, Chenopodiaceae, Poaceae, and Cyperaceae, which together make up over $80 \%$ of the total pollen in all samples (Fig. 3). Ephedra, Asteraceae p.p., Ranuculaceae, Caryophyllaceae (Arenaira-type), and Brassicaceae pollen also appear continuously in all samples, but in more moderate quantities that vary between 1 and $5 \%$ of the total pollen. The contribution of arboreal pollen taxa, including Pinus, Picea, Juniperus, Betula, and Ulmus, is relatively low, with a similar range between 1 and 5\%, and is dominated by Pinus.

In general, the fossil pollen sequence is characterised by a decrease in both Artemisia/Chenopodiaceae $(\mathrm{A} / \mathrm{C}$ ) ratios and total pollen concentrations from bottom to top, together with an increase in the arboreal pollen proportion (Fig. 4). The fossil pollen diagram is divided into three pollen-assemblage zones (PAZ 1-3) on the basis of the stratigraphically-constrained CONISS cluster analysis (Fig. 3), mainly reflecting variations in the relative abundances of Artemisia, Chenopodiaceae, and Pinus. The first assemblage zone (PAZ 1: $3770-2400$ cal a BP) is characterised by a trend in Chenopodiaceae values that first decrease and then increase, resulting in the opposite trend for the $\mathrm{A} / \mathrm{C}$ ratio. Values of Ephedra pollen show a gradually decreasing trend, while the total pollen concentration and arboreal pollen values are both low (Fig. 4b, d). The second assemblage zone (PAZ 2: $2400-900 \mathrm{cal}$ a BP) shows fluctuations in the Artemisia and Chenopodiaceae values. Chenopodiaceae shows an abrupt increase at about $1700 \mathrm{cal}$ a BP, lasting around 100 years. Arboreal pollen increases in parallel with a decreasing total pollen concentration (Fig. 4d). The PAZ 3 assemblage is characterised by the general replacement of Artemisia by Chenopodiaceae after $900 \mathrm{cal}$ a BP, resulting in a continuing decrease in the $\mathrm{A} / \mathrm{C}$ ratio, while Arenaria- 


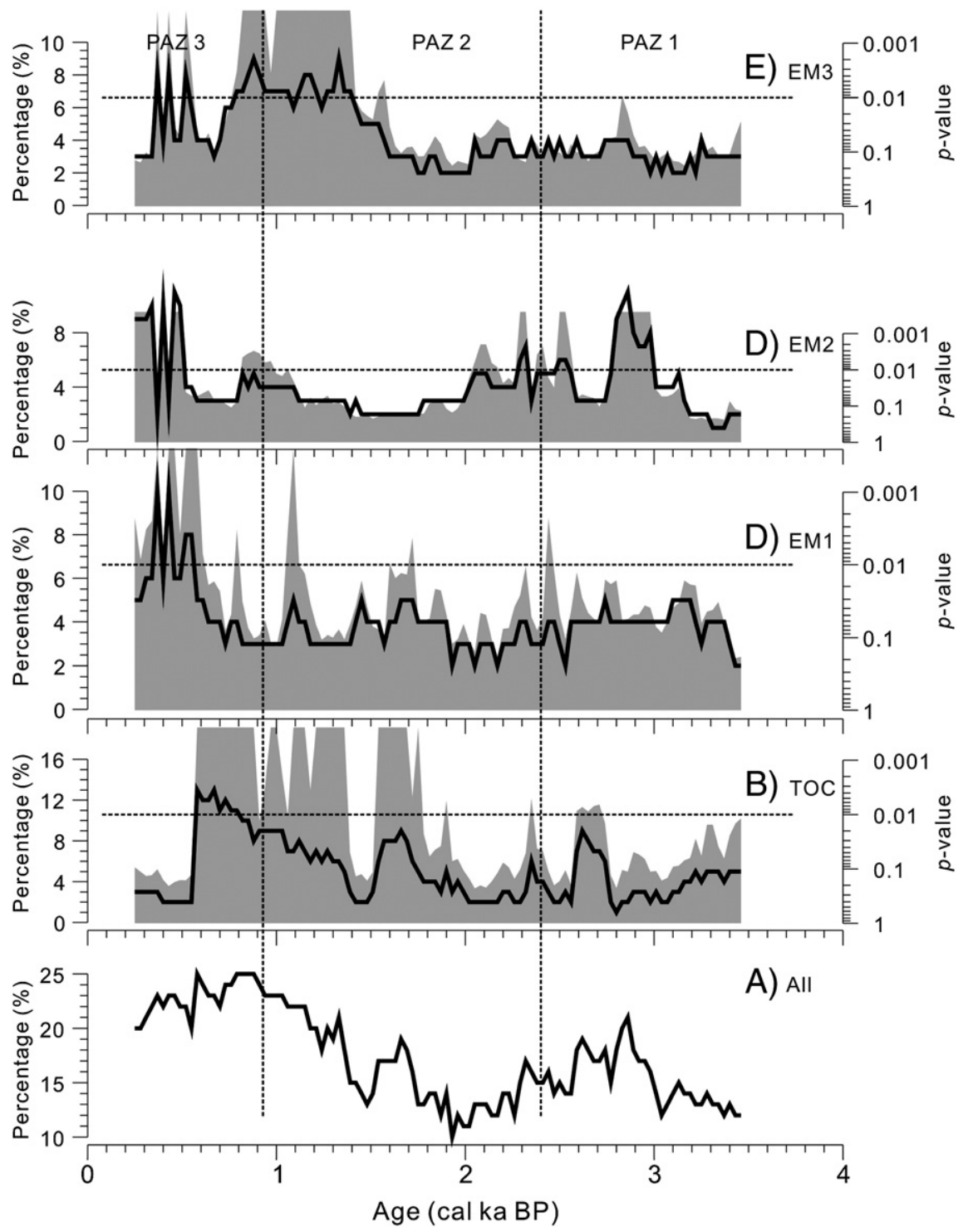

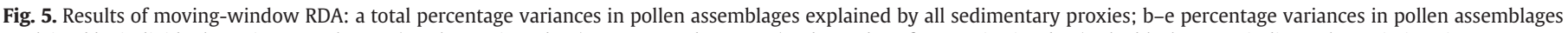

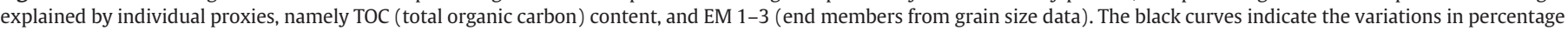

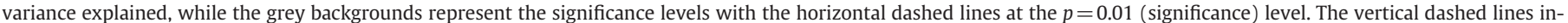
dicate the boundaries between pollen-assemblage zones.

type and arboreal pollen values (especially Pinus) reach their maxima (Fig. 3; Fig. 4d).

\subsection{Pollen-environment correlations}

Among the environmental proxies, the highest correlation was detected between EM1 and EM4 $\left(r^{2}=-0.70\right)$, while moderate values were found between TOC and TIC (0.60), TOC and EM4 (0.54), TIC and EM1 ( -0.53$)$, TOC and EM1 ( -0.50$)$ (Table 2). The PCA analysis for

Table 3

Summary of Procrustes Analysis between each pair of sections: Procrustes sum of squares (values in bold) and Procrustes Root Mean Squared Errors (values in italic).

\begin{tabular}{lllllllllllllll}
\hline \multicolumn{3}{c}{ KSH } & \multicolumn{2}{l}{ KSH 5 } & \multicolumn{1}{l}{ KSH 4 } & \multicolumn{1}{l}{ KSH 3 } & \multicolumn{1}{l}{ KSH 2 } & \multicolumn{3}{l}{ KSH 1 } \\
\hline KSH 6 & - & - & $\mathbf{0 . 7 1}$ & 0.25 & $\mathbf{0 . 7 4}$ & 0.26 & $\mathbf{0 . 8 5}$ & 0.28 & $\mathbf{0 . 7 4}$ & 0.26 & $\mathbf{0 . 7 6}$ & 0.26 \\
KSH 5 & - & - & - & - & $\mathbf{0 . 7 5}$ & 0.26 & $\mathbf{0 . 7 4}$ & 0.26 & $\mathbf{0 . 6 7}$ & 0.25 & $\mathbf{0 . 8 4}$ & 0.28 \\
KSH 4 & - & - & - & - & - & - & $\mathbf{0 . 6 6}$ & 0.24 & $\mathbf{0 . 6 5}$ & 0.24 & $\mathbf{0 . 5 9}$ & 0.23 \\
KSH 3 & - & - & - & - & - & - & - & - & $\mathbf{0 . 7 5}$ & 0.26 & $\mathbf{0 . 5 5}$ & 0.22 \\
KSH 2 & - & - & - & - & - & - & - & - & - & - & $\mathbf{0 . 1 2}$ & 0.11 \\
KSH 1 & - & - & - & - & - & - & - & - & - & - & - & - \\
\hline
\end{tabular}

all the sedimentary proxies reveals strong correlations between TOC, TIC, and EM4, as shown by their close distribution on the PCA bi-plot (Supplementary, Figure S1). In order to reduce the collinearity within the environmental proxies as well as to retain enough variables, TIC and EM4 were excluded from further numerical analyses.

The apparent gradually increasing total amount of variance in the pollen assemblages from bottom to top is explained statistically by the sedimentary proxies as environmental variables in a moving-

Table 4

Summary of ProTest between each pair of sections: correlation in a symmetric Procrustes rotation (values in bold) and significance based on 11 permutations (values in italic).

\begin{tabular}{|c|c|c|c|c|c|c|c|c|c|c|c|}
\hline & $\begin{array}{l}\text { KSH } \\
6\end{array}$ & KSH & & $\mathrm{KSH}$ & & $\mathrm{KSH}$ & & KSH 2 & & $\mathrm{KSH}$ & \\
\hline KSH 6 & $-\quad-$ & 0.54 & 0.27 & 0.51 & 0.18 & 0.39 & 0.36 & 0.51 & 0.27 & 0.49 & 0.27 \\
\hline KSH 5 & - - & - & - & 0.50 & 0.09 & 0.51 & 0.09 & 0.57 & 0.09 & 0.40 & 0.45 \\
\hline KSH 4 & $-\quad-$ & - & - & - & - & 0.59 & 0.09 & 0.59 & 0.09 & 0.64 & 0.09 \\
\hline KSH 3 & - - & - & - & - & - & - & - & 0.50 & 0.09 & 0.67 & 0.09 \\
\hline KSH 2 & $-\quad-$ & - & - & - & - & - & - & - & - & 0.94 & 0.09 \\
\hline KSH 1 & - - & - & - & - & - & - & - & - & - & - & - \\
\hline
\end{tabular}


window-RDA (Fig. 5a). Except for the first few centuries after 3000 cal a BP, PAZ 1 is characterised by a relatively low explained variance of around $15 \%$ in pollen assemblages by the constraining environmental factors, while PAZ 2 is dominated by a continuously increasing trend in the total explained variance from about $15 \%$ to 25\%. The highest explained variances are detected during PAZ 3 , reaching up to $25 \%$.

The TOC content in the sediment is generally low, varying between $0.6 \%$ and $2.4 \%$ (Fig. 4 e), which explains a significant part of the variance in the pollen assemblages during PAZ 2, as well as at the beginning of PAZ 3, generally contributing around $8 \%$ and up to $13 \%$ to the total explained variances (Fig. 5b).

Four end-members (EMs) were deduced from the EMMA analysis of the grain-size data (Fig. 4g; Liu et al., 2009), with EM1 having the coarsest grain-size fraction, generally over $100 \mu \mathrm{m}$. The EM2 and EM3 end-members consist mainly of the intermediate fractions, with predominant modal grain sizes of $40 \mu \mathrm{m}$ and $10 \mu \mathrm{m}$, respectively, which are consistent with the grain-size distributions for presentday aeolian samples. The EM4 end-member is characterised by the finest fraction (ca. $4 \mu \mathrm{m}$ ). The variance in pollen assemblages explained by EM1 is generally low (below 4\%), and is insignificant except during the last few centuries (Fig. 5c). Variations in correlations in EM2 could, to a large extent, explain the variations in pollen assemblages during the transition from PAZ 1 to PAZ 2, as well as during the last few centuries (Fig. 5d). The EM3, on the other hand, plays a highly significant role of around $8 \%$ between 1500 and 800 cal a BP (Fig. 5e).

\subsection{Procrustes and ProTest analyses}

As shown in Table 3, relatively higher Procrustes sum-of-squares are found between the youngest section (KSH 6) and the older sections (KSH 1-5), indicating generally higher dissimilarities between KSH 6 and the older sections. Consistently, the ProTest shows rather lower correlations in a symmetric Procrustes rotation between KSH 6 and the older section (KSH 1-5), which has the same inferences as the Procrustes analysis (Table 4). Considering that we have used the pollen species correlation matrices for the Procrustes and ProTest analyses, both results indicate that the pollen species correlations in section KSH 6 are different from those in the other sections. In contrast, generally consistent pollen species correlations dominate during these older periods of time, with only minor differences.

\subsection{Artemisia time-series analysis}

The spectral analysis on the original Artemisia percentages reveals statistically significant multi-decadal periodicities with intervals of $27,31,33$, and 36 years with a greater than $90 \%$ confidence level, as well as a millennial scale periodicity of 1512 years (Fig. 2A). However, using the data that had been re-sampled at 15 year intervals, the signals of multi-decadal periodicities tended to disappear (Fig. 2B) leaving only the millennial signal consistent with the results from the original data.

\section{Discussion}

\subsection{Environmental indicator value of individual sedimentary proxies}

In view of the low organic carbon to nitrogen $(\mathrm{C} / \mathrm{N})$ ratios (below 10; Liu et al., 2009), the TOC content recovered from our sediment samples can generally be taken to be representative of the primary productivity within the lake system (Meyers and Lallier-Verges, 1999). Furthermore, the variations in TOC content show patterns that are consistent with precipitation reconstructions based on treerings from Delingha in the northern part of the Tibetan Plateau (Shao et al., 2005), indicating that the TOC-related primary productivity in Lake Kusai may be largely controlled by changes in precipitation, as has been widely reported from the arid and semiarid regions in central Asia (e.g. Shen et al., 2005; Xiao et al., 2002, 2006; Mischke et al., 2010). Productivity in the lake increased during periods of higher precipitation resulting in a higher TOC content in the sediments, and conversely decreased during drier periods.

X-ray diffraction (XRD) analysis has revealed that the carbonate minerals in the sediments from Lake Kusai consist mainly of aragonite, which is commonly reported to be an autogenic mineral on the Tibetan Plateau (Wang et al., 2012), and which has also been considered to be biogenic because of the high ostracod content in the sediments (Wang, unpublished data; Yao et al., 2011). The distribution of ostracods has been shown to be sensitive to lake-water salinity (Mischke et al., 2007, 2010). Since Lake Kusai is currently a brackish lake, any variations in salinity are likely to have a considerable influence on the subsistence of ostracods and the corresponding TIC content in the sediments. Generally, for closed basin lakes in arid regions, a salinity change is most closely related to regional climate, especially moisture changes, which is possibly the reason for the strong collinear variations between TIC and TOC.

The EMMA analysis has been widely applied to identify possible sources of sediments in ocean and lake sedimentary sequences (Weltje and Prins, 2003, 2007; Liu et al., 2009). The first end-member, the sand-size fraction, is considered by Liu et al. (2009) to represent glacially supplied material. However, the northern Tibetan Plateau has been recognised as an area that is greatly influenced by dust-storm events (Wang et al., 2004a), and analyses on modern dust samples collected at Lenghu Meteorological Station have revealed that, in the Qinghai-Tibet area, the coarse grain-size fraction $(>63 \mu \mathrm{m})$ is an indicator of dust-storm events (Qiang et al., 2007a,b). We therefore interpret EM1 to represent coarse sands derived during dust-storm events (Wang et al., 2009). In contrast, the intermediate fractions, EM2 and EM3, represent grain-size distributions matching those of modern aeolian dust samples that were collected from Lake Kusai during an expedition in the winter of 2009, and so could indicate the intensity of regular aeolian activities (Liu et al., 2009). Considering the fact that, in arid regions, rivers with low discharge rates are usually incapable of transporting coarse particles into the central part of a lake, EM4 was interpreted to represent non-aeolian mud associated with fluvial processes (Liu et al., 2009). In such arid regions, aeolian dust events are highly dependent on the regional vegetation cover, which can significantly influence the erosion and transport of soils. Reduced vegetation cover can enhance the intensities of aeolian activities (Wolfe and Nickling, 1993; Ludwig et al., 2005).

Our analysis of pollen from Lake Kusai has revealed that the northern part of the Tibetan Plateau was characterised by high values of Artemisia and Chenopodiaceae during the late-Holocene, which is generally consistent with results obtained by other investigators from nearby sites such as Lake Qinghai (Liu et al., 2002; Shen et al., 2005), Lake Hurleg (Zhao et al., 2007), Lake Kuhai (Wischnewski et al., 2011), and Lake Donggi Cona (Wang et al., submitted for publication). For pollen records from arid and semi-arid areas, the $\mathrm{A} / \mathrm{C}$ ratio has been shown to be a reliable indicator for changes in moisture levels owing to the different ecological tolerances of Artemisia and Chenopodiaceae (Campo et al., 1996; Cour et al., 1999; Herzschuh et al., 2003, 2004; Herzschuh, 2007). In contrast, the arboreal pollen in samples from arid steppe or desert regions, and especially those pollen grains with air sacs (i.e. Pinus), are commonly considered to represent long-distance transport (Lu et al., 2010), with a high content of such grains indicating limited local pollen productivity as a result of relatively dry conditions or reduced vegetation cover. Variations in pollen concentrations have traditionally been interpreted in terms of changes in vegetation and/or climate, but such interpretations should be treated with caution because of variations in species-specific pollen productivities. For instance, when the climate becomes drier, the slight increase in Chenopodiaceae in the vegetation is accompanied by a marked decrease in Artemisia, but could still lead to an increase in 
pollen concentration owing to its high productivity despite an opening up of the vegetation cover (Wang and Herzschuh, 2011). Furthermore, since our study area is located close to the arid, low-elevation Qaidam Basin, which is dominated by desert plants (Zhao et al., 2007, 2010), this may have affected the pollen assemblages recovered due to the high transportability of Chenopodiaceae pollen, as has previously been discussed for the north-eastern part of the Tibetan Plateau at Lake Donggi Cona (Wang et al., submitted for publication) and Lake Kuhai (Wischnewski et al., 2011).

\subsection{Vegetation changes during the late-Holocene and possible drivers}

\subsubsection{From 3770 to 2400 cal a BP: vegetation fluctuations under abrupt} climate changes

The gradual expansion of alpine desert over the extensive alpine steppe that we observed at around $4000 \mathrm{cal}$ a BP has also been reported from Lake Zigetang (Herzschuh et al., 2006), Lake Kuhai (Wischnewski et al., 2011), Lake Donggi Cona (Wang et al., submitted for publication) and Lake Hurleg (Zhao et al., 2007) (Fig. 3). The correlations between pollen and the individual sedimentary proxies show marked fluctuations at low statistical significance levels (Fig. 5), which is why there is a rather low total variance explained compared to later periods. Significant correlations could be identified for the lake system (TOC) and the aeolian component (EM2), but none of these persist.

High $\mathrm{A} / \mathrm{C}$ ratios together with low arboreal pollen values during this period are suggestive of a relatively wet condition, which is consistent with the results of previous investigations into the evolution of the Asian Summer Monsoon (ASM) (Dykoski et al., 2005; Wang et al., 2005, 2010). During this period, the ASM was still undergoing a retreat. Such rapid climate change possibly caused strong fluctuations in regional vegetation composition, reflected in the high compositional turnover indicated by the DCCA (Fig. 4c). The terrestrial and aquatic environments may exhibit different time-lags in their responses to these oscillations and periods of disequilibrium between climate and the ecosystems may then predominate, resulting in low correlations between pollen assemblages and the sedimentary proxies. Such an effect has been previously reported from a multi-proxy study on Lake Kuhai, in the north-eastern part of the Tibetan Plateau (Wischnewski et al., 2011).

\subsubsection{From 2400 to $900 \mathrm{cal}$ a BP: gradual decrease in vegetation coverage}

Minor fluctuations between alpine steppe and alpine desert are still obvious during this period, but they are characterised by lower amplitudes, which are also indicated by the lower compositional turnover indicated by DCCA (Fig. 4c). Rather stable environmental conditions have been reported from nearby lakes on the basis of their pollen assemblages (Liu et al., 2002; Shen et al., 2005; Zhao et al., 2007; Wischnewski et al., 2011; Wang et al., submitted for publication) and geochemical proxies (Ji et al., 2005; Mischke et al., 2009; Henderson et al., 2010).

Highly significant correlations between pollen assemblages and TOC characterise the period after $1800 \mathrm{cal}$ a BP, which has been assumed from stalagmite records to have been a period with a relatively stable ASM (Dykoski et al., 2005; Wang et al., 2005). Such stable conditions with relatively high effective moisture favoured both the development of alpine steppe vegetation and primary productivity in the lake, resulting in the high concordance observed between the pollen assemblages and the TOC content. However, following the sudden decrease in the strength of the ASM after $1700 \mathrm{cal}$ a BP (Dykoski et al., 2005) the pollen assemblages show significant correlations with aeolian activity (EM3). This suggests that changes in the moisture levels are only critical for vegetation change during times of generally high and stable moisture levels, such as during periods of highly significant correlations between pollen assemblages and TOC that occurred from 3200 to $3400 \mathrm{cal}$ a BP and 2000 to 1400 cal a BP (Fig. 5b), when high A/C ratios are also found (Fig. 4a). In contrast, during periods with rather low moisture levels (such as after $1400 \mathrm{cal}$ a BP) the vegetation became more sensitive to extreme events and instabilities indicated by aeolian dust and fluvial input, rather than to the general climatic trends.

This argument is further supported by variations in total pollen concentration. It has been previously established that, on the Tibetan Plateau, Chenopodiaceae has the highest pollen productivity and representation of the common alpine taxa (Wang and Herzschuh, 2011). Thus, at the time of the switch from Artemisia to Chenopodiaceae which occurred at around $2800 \mathrm{cal}$ a BP, the total pollen concentration also increased. Although drier climatic conditions indicated by the expansion of alpine desert may have constrained the productivity of regional vegetation, the overall pollen productivity increased as a result of the appearance of high pollen producting Chenopodiaceae. However, when another switch from Artemisia to Chenopodiaceae occurred at around $1500 \mathrm{cal}$ a BP, the total pollen concentration decreased, which possibly indicates that even the growth of Chenopodiaceae was restricted due to extremely limited moisture availability. This hypothesis may be supported by the high content of arboreal pollen at this time, in particular, pollen of Pinus, which is indicative of long-distance extra-regional transport and is well represented during times of low local and regional pollen productivity. A reduced cover of regional vegetation was probably responsible for the intensification of surface erosion by both wind and surface runoff, producing the high levels of correlation observed between pollen assemblages and the EM3 grain-size parameters (Fig. 5e). A critical threshold in vegetation cover may have been crossed, beyond which vegetation composition was driven by sudden, severe climatic events rather than by general climatic changes.

\subsubsection{From 900 cal a BP to present: introduction of human impact as a main driver of vegetation change}

The last 900 years have been characterised by a gradual expansion of alpine desert, replacing alpine steppe; this is indicative of a further decrease in effective moisture and is consistent with pollen results from the Qaidam Basin (Zhao et al., 2010), the stalagmite record from Wanxiang Cave (Zhang et al., 2008), and the precipitation index from Longxi (Tan et al., 2008). The lake's internal variables, such as TIC content, show the highest levels of correlation with pollen assemblages. Since aragonite dominates the carbonate minerals of Lake Kusai and possibly has a biogenic origin (e.g., from ostracod shells) (Wang, 2008; Yao et al., 2011), the decreasing TIC content may relate to unfavourable living conditions for ostracods such as high salinity levels in the lake-water, as has been reported for Lake Ulungur in northern China since 1200 cal a BP (Jiang et al., 2008; Mischke and Zhang, 2011).

The lowest total pollen concentration and the highest content of long-distance transported arboreal pollen (Pinus) are both recorded during this period, indicating a further decrease in regional vegetation cover. Meanwhile, the lake's external environmental factors changed to coarser grain-size fractions as indicated by EM1 and EM2, particularly after 500 cal a BP (Fig. 5c, d), indicating intensified aeolian activity and even dust-storm events as a result of the reduced vegetation cover, such as commonly occur in this region (Qiang et al., 2007a; Wang et al., 2009). Furthermore, modern ecosystem studies have shown that the introduction of human impacts would have reduced the climatic resilience of the alpine vegetation communities, leading to high correlations between vegetation changes and non-climatic severe events (Wang et al., 2004b).

Interestingly, our Procrustes and ProTest analyses reveal different taxon interrelationships for the pollen records after 600 cal a BP from those for the earlier periods (Table 3; Table 4). Given the low vegetation diversity in this part of the Plateau, it is unlikely that an extensive plant species exchange (that is not visible at the genus or family levels of pollen analyses) would be the cause of these changes in the inter-relationships between pollen taxa. Human impacts on the vegetation are more likely to have altered the former inter-species 
relationships. Human impacts on marginal areas of the Plateau have been inferred to extend back as far as $8800 \mathrm{cal}$ a BP (Guo et al., 2006; Dearing et al., 2008; Meyer et al., 2009; Miehe et al., 2009), although only one Neolithic archaeological site (at Chugong, $5 \mathrm{~km}$ from Lhasa), dated to around $3700 \mathrm{cal}$ a BP, has been reported so far (Aldenderfer, 2007). Pollen records from lakes and peat in the eastern part of the Plateau, however, indicate increased grazing activities during the late-Holocene, dating from about $3400 \mathrm{cal}$ a BP in the Hengduan Mountains (Kramer et al., 2010) and from about $2200 \mathrm{cal}$ a BP in the Nianbaoyeze Mountains (Schlütz and Lehmkuhl, 2009). In addition, by synthesising both pollen and non-pollen records from central Asia, Wang et al. (2010) reported that the pollen records have possibly been affected by human impacts during the last 1000 years. Humans appear to have only reached the northern parts of the Tibetan Plateau around $600 \mathrm{cal}$ a BP, probably because of its remoteness and the extremes of weather (e.g., dust storms), leading to sustained changes in vegetation.

\subsection{Underlying climatic mechanisms}

As discussed above, the gradually decreasing $\mathrm{A} / \mathrm{C}$ ratio and total pollen concentrations, together with the increasing arboreal pollen content, indicate a gradual decrease in effective moisture during the late-Holocene, which is generally consistent with previously reported results from the Tibetan Plateau and adjacent regions, e.g., Lake Zigetang (Herzschuh et al., 2006), Lake Qinghai (Shen, et al., 2005), Lake Luanhaizi (Herzschuh et al., 2010b), Lake Yidun (Shen et al., 2006), Lake Hidden and Lake Renco (Tang et al., 2000). In addition, synthesised moisture evolution for the monsoonal regions shows identical patterns during the late-Holocene, indicating a gradual decline in the ASM (Herzschuh, 2006; Wang et al., 2010), which is also recorded in Asian stalagmites (Fleitmann et al., 2003; Dykoski et al., 2005; Wang et al., 2005) and in marine sediments from the Arabian Sea (Overpeck et al., 1996; Gupta et al., 2003). Changes in the climate on the northern Tibetan Plateau during the late Holocene were therefore probably a response to changes in the ASM system (Liu et al., 2009).

There is, however, no evidence in our pollen record for an increase in ASM intensity during the last few centuries that has been frequently interpreted from stalagmites (Fleitmann et al., 2003; Dykoski et al., 2005; Wang et al., 2005). Such signals might have become blurred by the parallel appearance of major human impacts on the vegetation. However, the $\mathrm{A} / \mathrm{C}$ ratio yielded higher values at about $300 \mathrm{cal}$ a $\mathrm{BP}$, indicating a relatively wet phase that is temporally consistent with the Little Ice Age (LIA) (Fig. 4) and which was also detected in the pollen record from the Dunde ice-core (Liu et al., 1998). An increase in effective moisture during the cool LIA has been deduced from carbonate oxygen isotopes from Lake Qinghai, and is considered to be due to a reduction in evaporation caused by colder air temperatures and an increase in the relative importance of moisture-bearing westerlies (Henderson et al., 2010). In addition, our Artemisia-based timeseries analysis reveals a significant periodicity of 1512 years which is consistent with the 1500 year "Bond Cycle" from the North Atlantic (Bond et al., 2001). Despite the relatively short record that we have used, the obvious periodicities in both the $\mathrm{A} / \mathrm{C}$ ratio and the pollen assemblages may indicate possible teleconnections between climate changes in central Asia and the North Atlantic, through the midlatitude westerlies jet-stream (Vandenberghe et al., 2006). However, owing to the limited time-span of our record, such teleconnections must be investigated further in future studies.

\section{Conclusions}

In summary, the susceptibility of late-Holocene vegetation in the northern part of the Tibetan Plateau to various environmental triggers has changed over the course of time. Identical responses to climate changes have been identified in regional vegetation for periods under generally wet and stable conditions. Following a threshold for vegetation cover at around $1500 \mathrm{cal}$ a $\mathrm{BP}$, the vegetation response became more sensitive to severe events, which led to increases in the correlation with both aeolian and fluvial transportation. The extensive and broad-scale impacts of humans on the natural ecosystems of the northern Tibetan Plateau appear not to have started until about 600 cal a BP. Our results therefore generally indicate that a range of factors may have acted as drivers for changes in the former vegetation composition, and that each of these various possibilities needs be taken into account when interpreting fossil pollen records.

\section{Acknowledgements}

The authors would like to thank Bo Yang (Institute of Salt Lakes, CAS) and Rong Wang (Nanjing Institute of Geography and Limnology, CAS) for their help during the field work. Janett Borkowski (University of Potsdam) is also acknowledged for her assistance in data handling. We are grateful to Dr. Richard Telford (University of Bergen) for his valuable advice on the numerical analyses. The research was supported by the Strategic Priority Research Program of the Chinese Academy of Sciences (Grant No. XDA05080403), the China Global Change Research Program (Grant No. 2010CB950101), the German Research Foundation (DFG), and the "Helmholtz-China Scholarship Council Young Scientist Fellowship." The authors are grateful to Dr. Peter Kershaw (editor) and one anonymous reviewer for their valuable suggestions.

\section{Appendix A. Supplementary data}

Supplementary data to this article can be found online at http:// dx.doi.org/10.1016/j.palaeo.2012.06.022.

\section{References}

Aitchison, J., 1990. Relative variation diagrams for describing patterns of compositional variability. Mathematical Geology 22, 487-511.

Aldenderfer, M.S., 2007. Modeling the Neolithic on the Tibetan Plateau. Developments in Quaternary Sciences 9, 151-165.

Bond, G., Kromer, B., Beer, J., Muscheler, R., Evans, M.N., Showers, W., Hoffmann, S., Lotti-Bond, R., Hajdas, I., Bonani, G., 2001. Persistent solar influence on North Atlantic climate during the Holocene. Science 294, 2130-2136.

Bradshaw, E.G., Rasmussen, P., Odgaard, B.V., 2005. Mid- to late-Holocene land-use change and lake development at Dallund Sø, Denmark: synthesis of multiproxy data, linking land and lake. The Holocene 15, 1152-1162.

Campo, E.V., Cour, P., Hang, S.X., 1996. Holocene environmental changes in Bangong Co basin (Western Tibet). Part 2: The pollen record. Palaeogeography Palaeoclimatology Palaeoecology 120, 49-63.

Cour, P., Zheng, Z., Duzer, D., Calleja, M., Yao, Z., 1999. Vegetational and climatic significance of modern pollen rain in northwestern Tibet. Review of Palaeobotany and Palynology 104, 183-204.

Dallmeyer, A., Claussen, M., Herzschuh, U., Fischer, N., 2011. Holocene vegetation and biomass changes on the Tibetan Plateau - a model-pollen data comparison. Climate of the Past 7, 881-901.

Dearing, J.A., Jones, R.T., Shen, J., Yang, X., Boyle, J.F., Foster, G.C., Crook, D.S., Elvin, M.J.D., 2008. Using multiple archives to understand past and present climatehuman-environment interactions: the lake Erhai catchment, Yunnan Province, China. Journal of Paleolimnology 40, 3-31.

$\mathrm{R}$ Development Core Team, 2011. R: A language and environment for statistical computing. R Foundation for Statistical Computing, Vienna, Austria. ISBN 3-90005107-0, URL http://www.R-project.org/.

Dykoski, C.A., Edwards, R.L., Cheng, H., Yuan, D.X., Cai, Y.J., Zhang, M.L., Lin, Y.S., Qing, J.M., An, Z.S., Revenaugh, J., 2005. A high-resolution, absolute-dated Holocene and deglacial Asian monsoon record from Dongge Cave, China. Earth and Planetary Science Letters 233, 71-86.

Fægri, K., Iversen, J., 1989. Textbook of Pollen Analysis, 4th edition. John Wiley and Sons, Chichester. 328 pp.

Fleitmann, D., Burns, S.J., Mudelsee, M., Neff, U., Kramers, J., Mangini, A., Matter, A., 2003. Holocene forcing of the Indian Monsoon recorded in a stalagmite from southern Oman. Science 300, 1737-1939.

Fontes, J.C., Gasse, F., Gibert, E., 1996. Holocene environmental changes in Lake Bangong basin (Western Tibet). Part 1: Chronology and stable isotopes of carbonates of a Holocene lacustrine core. Palaeogeography Palaeoclimatology Palaeoecology $120,25-47$.

Gasse, F., Arnold, M., Fontes, J.C., Fort, M., Gibert, E., Huc, A., Li, B.Y., Li, Y.F., Liu, Q. Melieres, M., Campo, E.V., Wang, F.B., Zhang, Q.S., 1991. A 13000-year climate record from western Tibet. Nature 353, 742-745. 
Grimm, E.C., 1991. TILIA and TILIAGRAPH Software. Illinois State Museum, Springfield

Guo, S., Savolainen, P., Su, J., Zhang, Q., Qi, D., Zhou, J., Zhong, Y., Zhao, X., Liu, J., 2006. Origin of mitochondrial DNA diversity of domestic yaks. BMC Evolutionary Biology $6,73$.

Gupta, A.K., Anderson, D.M., Overpeck, J.T., 2003. Abrupt changes in the Asian southwest monsoon during the Holocene and their links to the North Atlantic Ocean. Nature 421, 354-357.

Henderson, A.C.G., Holmes, J.A., Leng, M.J., 2010. Late Holocene isotope hydrology of Lake Qinghai, NE Tibetan Plateau: Effective moisture variability and atmospheric circulation changes. Quaternary Science Reviews 29, 2215-2223.

Herzschuh, U., 2006. Palaeo-moisture evolution in monsoonal Central Asia during the last 50,000 years. Quaternary Science Reviews 25, 163-178.

Herzschuh, U., 2007. Reliability of pollen ratios for environmental reconstructions on the Tibetan Plateau. Journal of Biogeography 34, 1265-1273.

Herzschuh, U., Kürschner, H., Ma, Y., 2003. The surface pollen and relative pollen production of the desert vegetation of the Alashan Plateau, western Inner Mongolia. Chinese Science Bulletin 48, 1488-1493.

Herzschuh, U., Tarasov, P., Wünnemann, B., Hartmann, K., 2004. Holocene vegetation and climate of the Alashan Plateau, NW China, reconstructed from pollen data. Palaeogeography Palaeoclimatology Palaeoecology 211, 1-17.

Herzschuh, U., Winter, K., Wünnemann, B., Li, S.J., 2006. A general cooling trend on the central Tibetan Plateau throughout the Holocene recorded by the Lake Zigetang pollen spectra. Quaternary International 154-155, 113-121.

Herzschuh, U., Birks, H.J.B., Ni, J., Zhao, Y., Liu, H.Y., Liu, X.Q., Grosse, G., 2010a. Holocene land-cover changes on the Tibetan Plateau. The Holocene 20, 91-104.

Herzschuh, U., Birks, H.J.B., Mischke, S., Zhang, C., Böhner, J., 2010b. A modern pollenclimate calibration set based on lake sediments from the Tibetan Plateau and its application to a Late-Quaternary pollen record from the Qilian Mountains. Journal of Biogeography 37, 752-766.

Herzschuh, U., Ni, J., Birks, H.J.B., Böhner, J., 2011. Driving forces of mid-Holocene vegetation shifts on the upper Tibetan Plateau, with emphasis on changes in atmospheric $\mathrm{CO}_{2}$ concentrations. Quaternary Science Reviews 30, 1907-1917.

Hill, M.O., Gauch, H.G., 1980. Detrended correspondence analysis: An improved ordination technique. Vegetatio 42, 41-58.

Hou, X., chief editor, 2001. Vegetation Atlas of China. Science Press, Beijing (in Chinese).

Ji, J.F., Shen, J. Balsam, W. Chen, J. Liu, L.W., Liu, X.Q. 2005. Asian monsoon oscillation in the northeastern Qinghai-Tibet Plateau since the late glacial as interpreted from visible reflectance of Qinghai Lake sediments. Earth and Planetary Science Letters $233,61-70$.

Jiang, Q.F., Shen, J., Liu, X.Q., Zhang, E.L., 2008. Holocene climate reconstructions of Ulungur Lake (Xinjiang, China) inferred from ostracod species assemblages and stable isotopes. Frontiers of Earth Science in China 2, 31-40.

Kramer, A., Herzschuh, U., Mischke, S., Zhang, C., 2010. Holocene tree line shifts and monsoon variability in the Hengduan Mountains (southeastern Tibetan Plateu), implications from palynological investigations. Palaeogeography Palaeoclimatology Palaeoecology 286, 23-41.

Li, B.Y., 1996. Environment of Kekexili area, Qinghai Province. Science Press, Beijing. (in Chinese)

Liu, K.B., Yao, Z.J., Thompson, L.G., 1998. A pollen record of Holocene climatic changes from the Dunde ice cap, Qinghai-Tibetan Plateau. Geology 26, 135-138.

Liu, X.Q., Shen, J., Wang, S.M., Yang, X.D., Tong, G.B., Zhang, E.L., 2002. A 16000-year pollen record of Qinghai Lake and its paleoclimate and paleoenvironment. Chinese Science Bulletin 47, 1931-1936.

Liu, X.Q., Dong, H.L., Yang, X.D., Herzschuh, U., Zheng, E.L., Stuut, J.W., Wang, Y.B., 2009. Late Holocene forcing of the Asian winter and summer monsoon as evidenced by proxy records from the northern Qinghai-Tibetan Plateau. Earth and Planetary Science Letters 280, 276-284.

Lu, X.M., Herrmann, M., Mosbrugger, V., Yao, T.D., Zhu, L.P., 2010. Airborne pollen in the Nam Co Basin and its implication for palaeoenvironmental reconstruction. Review of Palaeobotany and Palynology 163, 104-112.

Lu, H.Y., Wu, N.Q., Liu, K.B., Zhu, L.P., Yang, X.D., Yao, T.D., Wang, L., Li, Q., Liu, X.Q., Shen, C.M., Li, X.Q., Tong, G.B., Jiang, H., 2011. Modern pollen distributions in QinghaiTibetan Plateau and the development of transfer functions for reconstructing Holocene environmental changes. Quaternary Science Reviews 30, 947-966.

Ludwig, J.A., Wilcox, B.P., Breshears, D.D., Tongway, D.J., Imeson, A.C., 2005. Vegetation patches and runoff-erosion as interacting ecohydrological processes in seimiarid landscapes. Ecology 86, 288-297.

Meyer, M.C., Hofmann, Ch.-C.h., Gemmell, A.M.D., Haslinger, E., Häusler, H., Wangda, D. 2009. Holocene glacier fluctuations and migration of Neolithic yak pastoralists into the high valleys of northwest Bhutan. Quaternary Science Reviews 28, 1217-1237.

Meyers, P.A., Lallier-Verges, E., 1999. Lacustrine sedimentary organic matter records of Late Quaternary paleoclimates. Journal of Paleolimnology 21, 345-372.

Miehe, G., Miehe, S., Kaiser, K., Reudenbach, C., Behrendes, L., Duo, L., Schlütz, F., 2009. How old is pastoralism in Tibet? An ecological approach to the making of a Tibetan landscape. Palaeogeography Palaeoclimatology Palaeoecology 276, 130-147.

Miehe, G., Miehe, S., Bach, K., Kluge, J., Wesche, K., Yang, Y.P., Liu, J.Q., 2011. Ecological stability during the LGM and the mid-Holocene in the Alpine Steppes of Tibet? Quaternary Research 76, 243-252.

Mischke, S., Zhang, C.J., 2011. Ostracod distribution in Ulungur Lake (Xinjiang, China) and a reassessed Holocene record. Ecological Research 26, 133-145.

Mischke, S., Herzschuh, U., Massmann, G., Zhang, C.J., 2007. An ostracod-conductivity transfer function for Tibetan lakes. Journal of Paleolimnology 38, 509-524.

Mischke, S., Zhang, C., Börner, A., Herzschuh, U., 2009. Lateglacial and Holocene variation in aeolian sediment flux over the northeastern Tibetan Plateau recorded by laminated sediments of a saline meromictic lake. Journal of Quaternary Science 25 $162-177$.
Mischke, S., Aichner, B., Diekmann, B., Herzschuh, U., Plessen, B., Wünnemann, B., Zhang, C.J., 2010. Ostracods and stable isotopes of a late glacial and Holocene lake record from the NE Tibetan Plateau. Chemical Geology 276, 95-103.

Morrill, C., Overpeck, J.T., Cole, J.E., Liu, K.B., Shen, C.M., Tang, L.Y., 2006. Holocene variations in the Asian monsoon inferred from the geochemistry of lake sediments in central Tibet. Quaternary Research 65, 232-243.

Mortensen, M.F., Birks, H.H., Christensen, C., Holm, J., Noe-Nygaard, N., Odgaard, B.V., Olsen, J., Rasmussen, K.L., 2011. Lateglacial vegetation development in Denmark - New evidence based on macrofossils and pollen from Slotsen, a small-scale site in southern Jutland. Quaternary Science Reviews 30, 2534-2550.

Oksanen, J.F., Blanchet, G., Kindt, R., Legendre, P., Oksanen, J.F., Blanchet, G., Kindt, R., Legendre, P., O'Hara, R.B., Simpson, G.L., Solymos, P., Henry, M., Stevens, H., Wagner, H., 2011. R package version 1.17-12. Community Ecology Package, Vegan. http://CRAN.R-project.org/package= vegan.

Overpeck, J., Anderson, D., Trumbore, S., Prell, W., 1996. The southwest Indian Monsoon over the last 18000 years. Climate Dynamics 12, 213-225.

Paillard, D., Labeyrie, L., Yiou, P., 1996. Macintosh program performs time-series analysis. EOS Transactions AGU 77, 379.

Paradis, E., Claude, J., Strimmer, K., 2004. APE: analyses of phylogenetics and evolution in R language. Bioinformatics 20, 289-290.

Qiang, M.R., Chen, F.H., Zhang, J.W., Zu, R.P., Jing, M., Zhou, A.F., Xiao, S., 2007a. Grain size in sediments from Lake Sugan: a possible linkage to dust storm events at the northern margin of the Qinghai-Tibetan Plateau. Environmental Geology 51, 1229-1238.

Qiang, M.R., Chen, F.H., Zhou, A.F., Xiao, S., Zhang, J.W., Wang, Z.T., 2007b. Impacts of wind velocity on sand and dust deposition during dust storm as inferred from a series of observations in the northeastern Qinghai-Tibetan Plateau, China. Powder Technology 175, 82-89.

Reimer, P.J., Baillie, M.G.L., Bard, E., Bayliss, A., Beck, J.W., Bertrand, C.J.H., Blackwell, P.G, Buck, C.E., Burr, G.S., Cutler, K.B., Damon, P.E., Edwards, R.L., Fairbanks, R.G. Friedrich, M., Guilderson, T.P., Hogg, A.G., Hughen, K.A., Kromer, B., McCormac, F.G., Manning, S.W., Ramsey, C.B., Reimer, R.W., Remmele, S., Southon, J.R., Stuiver, M., Talamo, S., Taylor, F.W., van der Plicht, J., Weyhenmeyer, C.E, 2004. IntCal04, Terrestrial radiocarbon age calibration, 26-0 ka BP. Radiocarbon 46, 1029-1058.

Schlütz, F., Lehmkuhl, F., 2009. Holocence climatic change and the nomadic Anthropocene in Eastern Tibet: palynological and geomorphological results from Nianbaoyeze Mountains. Quaternary Science Reviews 28, 1449-1471.

Schulz, M., Mudelsse, M., 2002. REDEFIT: estimation red-noise spectra directly from unevenly spaced paleoclimatic time series. Computational Geosciences 28, 421-426.

Shao, X.M., Huang, L., Liu, H.B., Liang, E.Y., Fang, X.Q., Wang, L.L., 2005. Reconstruction of precipitation variation from tree ring in recent 1000 years in Delingha, Qinghai. Science in China Series D 48, 939-949.

Shen, J., Liu, X.Q., Wang, S.M., Matsumoto, R., 2005. Palaeoclimatic changes in the Qinghai Lake area during the last 18,000 years. Quaternary International 136, 131-140.

Shen, C.M., Liu, K.B., Tang, L.Y., Overpeck, J.T., 2006. Quantitative relationships between modern pollen rain and climate in the Tibetan Plateau. Review of Palaeobotany and Palynology 140, 61-77.

Shen, C.M., Liu, K.-B., Morrill, C., Overpeck, J.T., Peng, J.L., Tang, L.Y., 2008. Ecotone shift and major droughts during the mid-late Holocene in the central Tibetan Plateau. Ecology 89, 1079-1088.

Tan, L.C., Cai, Y.J., Li, L., An, Z.S., Ai, L., 2008. Precipitation variations of Longxi, northeast margin of Tibetan Plateau since AD 960 and their relationship with solar activity. Climate of the Past 4, 19-28.

Tang, L.Y., Shen, C.M., Liu, K.B., Overpeck, J.T., 2000. Changes in south Asian monsoon: new high-resolution paleoclimatic records from Tibet, China. Chinese Science Bulletin 45, 87-90.

Tang, L.Y., Shen, C.M., Li, C.H., Peng J.L, Liu, H., Liu, K.B., Morrill, C., Overpeck, JT., Cole, J.E., Yang, B., 2009. Pollen-inferred vegetation and environmental changes in the central Tibetan Plateau since 8200 yr BP. Science in China Series D 52, 1104-1114.

ter Braak, C.J.F., Šmilauer, P., 2002. CANOCO Reference Manual and CanoDraw for Windows User's Guide: Software for Canonical Community Ordination (version 4.5). Microcomputer Power, Ithaca (NY, USA). 500 pp.

van den Boogaart, K.G., Tolosana, R., Bren, M., 2011. compositions: Compositional Data Analysis. R package version 1.10-2. http://CRAN.R-project.org/package=compositions.

Vandenberghe, J., Renssen, H., Huissteden, K., Nugteren, G., Konert, M., Lu, H.Y., Dodonov, A., Buylaert, J.-P., 2006. Penetration of Atlantic westerly winds into Central and East Asia. Quaternary Science Reviews 25, 2380-2389.

Wang Y.B., 2008. A 4000-year climatic change inferred from Kusai lake of HohXil Region in the Nortern Tibetan Plateau. Master thesis, Nanjing Institute of Geography and Limnology, Chinese Academy of Sciences (in Chinese with English abstract)

Wang, S.M. and Dou, H.S. (chief eds), 1998. Lakes in China. Science Press, Beijing (in Chinese)

Wang, Y.B., Herzschuh, U., 2011. Reassess the Holocene vegetation change on the upper Tibetan Plateau using the pollen-based REVEALS model. Review of Palaeobotany and Palynology 168, 31-40.

Wang, X.M., Dong, Z.B., Zhang, J.W., Liu, L.C., 2004a. Modern dust storms in China: an overview. Journal of Arid Environments 58, 559-574.

Wang, G.X., Yao, J.Z., Guo, Z.G., Wu, Q.B., Wang, Y.B., 2004b. Changes in permafrost ecosystem under the influences of human engineering activities and its enlightenments to railway construction. Chinese Science Bulletin 49, 1741-1750.

Wang, Y.J., Cheng, H., Edwards, R.L., He, Y.Q., Kong, X.G., An, Z.S., Wu, J.Y., Kelly, M.J., Dykoski, C.A., Li, X.D., 2005. The Holocene Asian Monsoon links to solar changes and North Atlantic Climate. Science 308, 854-857.

Wang, Y.B., Liu, X.Q., Yang, X.D., Zhang, E.L., Yao, B., 2009. Dust storm events in Kekexili area, northern Tibetan Plateau during the past 4000 years: evidence from grain 
size analysis of lacustrine sediments in Kusai Lake. Acta Sedmentologica Sinica 27, 691-696 (in Chinese with English abstract).

Wang, Y.B., Liu, X.Q., Herschuh, U., 2010. Asynchronous evolution of the Indian and East Asian Summer Monsoon indicated by Holocene moisture patterns in monsoonal central Asia. Earth-Science Reviews 103, 135-153.

Wang, Y.B., Liu, X.Q., Mischke, S., Herzschuh, U., 2012. Environmental constraints on lake sediment mineral compositions from the Tibetan Plateau and implications for paleoenvironment reconstruction. Journal of Paleolimnology 47, 71-85.

Wang, Y.B., Herzschuh, U., Shumilovskikh, L., Mischke, S., Birks, H.J.B., Wischnewski, J., Böhner, J., Schlütz, F., Lehmkuhl, F., Diekmann, B., submitted for publication. Quantitative precipitation change on the NE Tibetan Plateau since the Last Glacial Maximum extending the concept of pollen source area to pollen-based climate reconstructions from large lakes. Quaternary Science Reviews.

Weisstein, E.W., 2012. Bonferroni Correction. From MathWorld-A Wolfram Web Resource. http://mathworld.wolfram.com/BonferroniCorrection.html2012(Accessed May 11, 2012).

Weltje, G., 1997. End-member modelling of compositional data: Numerical-statistical algorithms for solving the explicit mixing problem. Journal of Mathematical Geology 29, 503-549.

Weltje, G.J., Prins, M.A., 2003. Muddled or mixed? Inferring palaeoclimate from size distributions of deep-sea clastics. Sedimentary Geology 162, 39-62.

Weltje, G.J., Prins, M.A., 2007. Genetically meaningful decomposition of grain-size distributions. Sedimentary Geology 202, 409-424.

Wischnewski, J., Mischke, S., Wang, Y.B., Herzschuh, U., 2011. Reconstructing climate variability on the northeastern Tibetan Plateau since the last Late glacial - a multi-proxy, dual-site approach comparing terrestrial and aquatic signals. Quaternary Science Reviews 30, 82-97.
Wolfe, S.A., Nickling, W.G., 1993. The protective role of sparse vegetation in wind erosion. Progress in Physical Geography 17, 50-68.

Xiao, J.L., Nakamura, T., Lu, H.Y., Zhang, G.Y., 2002. Holocene climate changes over the desert/loess transition of north-central China. Earth and Planetary Science Letters 197, 11-18.

Xiao, J.L., Wu, J.T., Si, B., Liang, W.D., Nakamura, T., Liu, B.L., Inouchi, Y., 2006. Holocene climate changes in the monsoon/arid transition reflected by carbon concentration in Daihai Lake of Inner Mongolia. The Holocene 16, 551-560.

Yao, B., Liu, X.Q., Wang, Y.B., Yang, B., 2011. Late Holocene climatic changes revealed by mineralogy records from lacustrine core KS-2006 from Lake Kusai in the Kekexili area, northern Tibetan Plateau. Journal of Lake Science 23, 903-909 (in Chinese with English abstract).

Zhang, P.Z., Cheng, H., Edwards, R.L., Chen, F.H., Wang, Y.J., Yang, X.L., Liu, J., Tan, M., Wang, X.F., Liu, J.H., An, C.L., Dai, Z.B., Zhou, J., Zhang, D.Z., Jia, J.H., Jin, L.Y., Johnson, K.R., 2008. A test of climate, sun, and culture relationships from an 1810-Year Chinese cave record. Science 322, 940-942.

Zhao, Y., Yu, Z.C., Chen, F.H., Ito, E., Zhao, C., 2007. Holocene vegetation and climate history at Hurleg Lake in the Qaidam Basin, northwest China. Review of Palaeobotany and Palynology 145, 275-288.

Zhao, Y., Yu, Z.C., Liu, X.J., Zhao, C., Chen, F.H., Zhang, K., 2010. Late Holocene vegetation and climate oscillations in the Qaidam Basin of the northeastern Tibetan Plateau. Quaternary Research 73, 59-69.

Zhao, Y., Yu, Z.C., Zhao, W.W., 2011. Holocene vegetation and climate histories in the eastern Tibetan Plateau: controls by insolation-driven temperature or monsoonderived precipitation changes? Quaternary Science Reviews 30, 1173-1184. 